http://dx.doi.org/10.18778/1509-877X.2018.01.04

Artykuły

Jakub Jankowski*

\title{
MAPA LUKI PODATKOWEJ W PODATKU DOCHODOWYM OD OSÓB PRAWNYCH
}

\begin{abstract}
Streszczenie. W krajach wysokorozwiniętych od lat funkcjonują rozwiązania ukierunkowane na ograniczanie rozmiarów luki podatkowej w poszczególnych podatkach, wykorzystujące tzw. mapę luki podatkowej. W przypadku podatku dochodowego od osób prawnych szacowanie wysokości i struktury luki podatkowej w podatku dochodowym od osób prawnych jest o wiele bardziej skomplikowaną materią niż w przypadku podatku VAT. Ministerstwo Finansów podobno posiada swoje szacunkowe wyliczenia w tym zakresie, jednakże do dnia dzisiejszego nie zostały one opublikowane. Dostępna literatura zagraniczna dotyczącą szacowania strat podatkowych budżetu państwa z tytułu luki podatkowej dotyczy jedynie wybranych (partykularnych) obszarów luki podatkowej. Ponadto możliwości jej zastosowania w specyficznych uwarunkowaniach polskiego systemu podatkowego są ograniczone. W niniejszej publikacji podjęta została próba stworzenia mapy luki podatkowej dla celów podatku dochodowego od osób prawnych.
\end{abstract}

Słowa kluczowe: unikanie opodatkowania, przerzucanie dochodów, luka podatkowa, podatek dochodowy od osób prawnych

\section{WPROWADZENIE}

W krajach wysokorozwiniętych od lat funkcjonują rozwiązania ukierunkowane na ograniczanie rozmiarów luki podatkowej w poszczególnych podatkach, wykorzystujące tzw. mapę luki podatkowej ${ }^{1}$. W przypadku podatku

* Doktor nauk prawnych oraz doradca podatkowy, e-mail: j.jankowski@onet.eu

${ }^{1}$ Dla celów niniejszej publikacji pod pojęciem mapy luki podatkowej należy rozumieć szacunki (badania) dotyczące wielkości i struktury luki podatkowej w podatku dochodowym od osób prawnych (więcej zob. A. Klonowska, Rozpoznanie obszarów ryzyka 
dochodowego od osób prawnych szacowanie wysokości i struktury luki podatkowej jest o wiele bardziej skomplikowaną materią niż w przypadku podatku od towarów i usług. Ministerstwo Finansów podobno posiada swoje szacunkowe wyliczenia w tym zakresie, jednakże do dnia dzisiejszego nie zostały one opublikowane ${ }^{2}$. Dostępna literatura zagraniczna dotyczącą szacowania strat podatkowych budżetu państwa $z$ tytułu luki podatkowej dotyczy jedynie wybranych (partykularnych) obszarów luki podatkowej. Ponadto możliwości jej zastosowania w specyficznych uwarunkowaniach polskiego systemu podatkowego są ograniczone. W opracowaniu podjęto próbę stworzenia mapy luki podatkowej dla celów podatku dochodowego od osób prawnych?3.

\section{MOŻLIWOŚCI SZACOWANIA LUKI PODATKOWEJ W PODATKU DOCHODOWYM OD OSÓB PRAWNYCH}

Wśród sposobów szacowania luki podatkowej największe znaczenie mają dwie podstawowe metody:

- model ekonometryczny opisujący zależność między luką podatkową w danym podatku a zmiennymi wpływającymi na jej wysokość oraz

- procedura indukcji polegająca na oszacowaniu ubytku dochodów z podatku według jego przyczyn ${ }^{4}$.

Oszacowanie luki podatkowej w podatku dochodowym od osób prawnych jest materią niezwykle skomplikowaną w przeciwieństwie do estymacji luki podatkowej w podatku od towarów i usług 5 . W przypadku podatku

podatkowego jako metoda zwiększania wplywów podatkowych, rozprawa doktorska, Uniwersytet Ekonomiczny w Krakowie, Kraków 2016, s. 5).

${ }^{2}$ Wywiad z podsekretarzem stanu w Ministerstwie Finansów Pawłem Gruzą Wchodzimy w nowa faze uszczelniania luki podatkowej z dnia 3 kwietnia 2018 r., http:// biznes.interia.pl/podatki/news/wchodzimy-w-nowa-faze-uszczelniania-luki-podatkowej,2562811,4211 (dostęp: 11.04.2018).

${ }^{3}$ Dla celów niniejszego opracowania pod pojęciem luki podatkowej należy rozumieć różnicę między dochodami teoretycznymi a dochodami faktycznie uzyskanymi w danym roku podatkowym (por. E. Małecka-Ziembińska, Luka w podatku od towarów i usług i sposoby jej ograniczania, „Kwartalnik Kolegium Ekonomiczno-Społecznego Studia i Prace” 2017, nr 1, s. 46).

${ }^{4}$ M.M. Hybka, Struktura, metody szacowania oraz instrumenty ograniczania luki podatkowej w Wielkiej Brytanii i Stanach Zjednoczonych Ameryki, cz. 2, „Finanse, Rynki Finansowe, Ubezpieczenia" 2016, nr 5 (83), s. 189.

${ }^{5}$ M. Chądzyński, B. Godusławski, Uszczelnianie CIT bardziej skomplikowane niż VAT. W resorcie finansów sypią się głowy za opóźnienia, „Dziennik Gazeta Prawna” 5.04.2018. 
od towarów i usług możliwe jest bowiem stworzenie uniwersalnego wzoru na wyliczenie luki podatkowej poprzez odniesienie się do danych dotyczących konsumpcji ${ }^{6}$, natomiast dla celów podatku dochodowego od osób prawnych jest to niemożliwe z co najmniej kilku powodów:

- struktura luki podatkowej w podatku dochodowym od osób prawnych w przeciwieństwie do luki w podatku od towarów i usług jest rezultatem zarówno działań legalnych, jak i nielegalnych7;

- kluczowym czynnikiem kształtującym lukę podatkową w podatku dochodowym od osób prawnych jest działalność podatników ukierunkowana wyłącznie na obniżenie zobowiązania podatkowego poprzez optymalizację podatkową, natomiast błędy podatników w samowymiarze oraz niska wydajność aparatu skarbowego odgrywają mniejszą rolę w kreowaniu luki podatkowej w podatku dochodowym od osób prawnych;

- ubytki dochodów podatkowych z podatku dochodowego od osób prawnych są trudno obserwowalne (mało uchwytne) z perspektywy statystycznej;

- w zakresie podatku dochodowego od osób prawnych nie zostały praktycznie w ogóle zdiagnozowane branże gospodarki, które są w sposób szczególny narażone na zjawisko erozji podstawy opodatkowania9;

- luka podatkowa może przybierać zupełnie inny charakter w przypadku przedsiębiorstw z polskim kapitałem oraz firm z kapitałem zagranicznym ${ }^{10}$;

${ }^{6}$ Efektywność podatku VAT to stosunek wpływów z tego podatku do iloczynu podstawowej stawki VAT i całkowitej konsumpcji, tj. Efektywność podatku VAT = wptywy $z$ VAT

standardowa stawka VAT $\times$ konsumpcja

Raport Izby Gospodarczej Metali Niezależnych i Recyklingu „Luka podatkowa w podatku od towarów i usług” z 2012 r., http://inwestycje.pl/ resources/Attachment/2012/11_06/file16266.pdf (dostęp: 2.05.2018).

${ }^{7}$ W przypadku VAT główną przyczyną występowania luki podatkowej jest nielegalne uchylanie się od opodatkowania, które może polegać na prowadzeniu działalności gospodarczej w szarej strefie lub wyłudzeniu zwrotu podatku VAT w ramach tzw. karuzeli podatkowej.

${ }^{8}$ M. Sosnowski, Sprawność fiskalna podatków dochodowych, cz. 1, „Finanse, Rynki Finansowe, Ubezpieczenia” 2016, nr 5 (83), s. 50.

${ }^{9}$ K. Biernacki, A. Brodzka, M. Chodorek, Efektywne stawki podatku dochodowego w Polsce - na przykładzie spółek indeksu WIG 20, „Nauki o Finansach” 2016, nr 1 (26), s. 18.

${ }^{10}$ Przykładowo, firmy z polskim kapitałem nie posiadają zazwyczaj oddziałów za granicą i w przeciwieństwie do wielooddziałowych koncernów zagranicznych nie mogą korzystać z mechanizmów cen transferowych i przerzucać dochodów do jurysdykcji 
- determinanty wpływów podatkowych z podatku dochodowego od osób prawnych należy identyfikować dla poszczególnych państw z uwzględnieniem specyfiki systemu podatkowego danego państwa ${ }^{11}$.

$\mathrm{Z}$ tych powodów oszacowanie luki podatkowej w podatku dochodowym od osób prawnych $\mathrm{z}$ wykorzystaniem jednego uniwersalnego wzoru opartego na kilku zmiennych nie jest w praktyce wykonalne, dlatego też oszacowanie wysokości luki podatkowej w podatku dochodowym od osób prawnych powinno zostać dokonane na podstawie procedury indukcji.

\section{STRUKTURA LUKI PODATKOWEJ W PODATKU DOCHODOWYM} OD OSÓB PRAWNYCH WEDŁUG JEJ PRZYCZYN (PROCEDURA INDUKCJI)

Struktura luki podatkowej powinna uwzględniać podział na czynności legalne i nielegalne, który w przypadku podatku dochodowego od osób prawnych nie jest sprawą oczywistą i dla celów tworzenia mapy luki podatkowej konieczne jest dokonanie pewnych uproszczeń metodologicznych.

Pod pojęciem działań nielegalnych należy rozumieć przestępstwa uchylania się od opodatkowania w rozumieniu art. 54 i 56 Kodeksu karnego skarbowego ${ }^{12}$ (dalej: k.k.s.). W myśl tych przepisów uchylanie się od opodatkowania może polegać na następujących zachowaniach:

- nieujawnieniu właściwemu organowi przedmiotu lub podstawy opodatkowania, przez co podatek zostaje narażony na uszczuplenie (art. 54 k.k.s.);

- podaniu nieprawdy lub zatajeniu prawdy w złożonej deklaracji, przez co podatek zostaje narażony na uszczuplenie (art. 56 k.k.s.).

Analizując treść powołanych regulacji k.k.s., uchylanie się od opodatkowania należy zdefiniować jako eliminację lub ograniczenie wysokości zobowiązania podatkowego $\mathrm{w}$ sposób sprzeczny $\mathrm{z}$ obowiązującym porządkiem prawnym. W doktrynie prawa podatkowego jako synonimów pojęcia „uchylanie się od opodatkowania” używa się również terminów „oszustwo podatkowe” oraz

podatkowych o łagodniejszym systemie podatkowym (por. A. Grycuk, Podatek CIT jako narzędzie polityki gospodarczej, „Infos” nr 4 (74), 18.02.2010, s. 4.

${ }^{11}$ A. Adamczyk, Czynniki kształtujace dochody z tytułu podatku dochodowego od osób prawnych w Polsce na tle państw Unii Europejskiej, cz. 1, „Finanse, Rynki Finansowe, Ubezpieczenia” 2016, nr 5 (83), s. 16.

${ }^{12}$ Ustawa z dnia 10 września 1999 r. Kodeks karny skarbowy (tekst jedn. Dz.U. z 2017 r., poz. 2226 ze zm.). 
„brak dyscypliny podatkowej”'13. W praktyce obydwa te terminy wchodzą w zakres znaczeniowy pojęcia „uchylanie od opodatkowania”. Bezprawne uchylanie się od opodatkowania może bowiem zarówno być efektem braku świadomości podatnika co do istnienia zobowiązania podatkowego (tzw. brak dyscypliny budżetowej) ${ }^{14}$, jak i przybierać postać bezpośredniego i umyślnego naruszenia prawa podatkowego polegającego na podstępnym uchylaniu się od wymiaru lub uiszczenia całości bądź części podatku (tzw. oszustwo podatkowe) ${ }^{15}$. W konsekwencji dla celów mapy luki podatkowej podatku dochodowego od osób prawnych do kategorii „uchylanie się od opodatkowania” należy zaliczyć także zachowania podatników kwalifikowane przez doktrynę prawa podatkowego jako „oszustwo podatkowe” czy „brak dyscypliny podatkowej”.

Precyzyjna klasyfikacja legalnych metod redukcji ciężarów fiskalnych jest znacznie trudniejsza niż w przypadku czynności nielegalnych ze względu na niejednolity dorobek doktryny oraz judykatury. W przypadku legalnych metod wyróżnia się dwie podstawowe formy oporu podatkowego w postaci planowania podatkowego oraz unikania opodatkowania. Planowanie podatkowe to wykorzystywanie możliwości redukcji ciężarów fiskalnych w ramach i granicach obowiązujących przepisów podatkowych, niebudzące wątpliwości od strony etycznej i akceptowane przez władze podatkowe ${ }^{16}$. Unikanie opodatkowania to natomiast kształtowanie stosunków cywilnoprawnych w celu manewrowania obowiązkiem podatkowym i osiągnięcia stanu niższego opodatkowania w stosunku do oczekiwanego przez prawodawcę ${ }^{17}$. Działania podatnika następują w ramach istniejących przepisów, ale są niezgodne $\mathrm{z}$ duchem prawa podatkowego lub intencją ustawodawcy $^{18}$. Dochodzi wówczas do rozdźwięku pomiędzy skutkami

${ }^{13}$ M. Kurzac, Uchylanie się od opodatkowania i oszustwo podatkowe $w$ rozumieniu art. 54 i 56 Kodeksu karnego skarbowego w świetle odesłań do systemu prawa podatkowego, „Studia Prawno-Ekonomiczne” 2017, t. 102, s. 71.

${ }^{14}$ R. Sowiński, Uchylanie się od opodatkowania, Wydawnictwo Naukowe UAM, Poznań 2009, s. 14.

${ }^{15}$ P. Pietrasz, Opodatkowanie dochodów nieujawnionych, Wolters Kluwer, Warszawa 2007, s. 48.

${ }^{16}$ M. Kurzac, Unikanie opodatkowania a uchylanie się od opodatkowania - o kryteriach rozróżniających, „Studia Prawno-Ekonomiczne” 2017, t. 105, s. 13.

${ }^{17} \mathrm{~K}$. Radzikowski, Obejście prawa podatkowego w najnowszym orzecznictwie sądów administracyjnych, „Przegląd Podatkowy” 2010, nr 6, s. 10.

${ }^{18}$ B. Kuźniacki, Skuteczność polskich ogólnych norm prawnopodatkowych jako narzędzi potencjalnie stużacych zwalczaniu unikania opodatkowania przez wykorzystanie kontrolowanych zagranicznych spółek, „Toruński Rocznik Podatkowy” 2012, s. 31. 
podatkowymi i ekonomicznymi transakcji poprzez oderwanie podstawy opodatkowania od treści ekonomicznej transakcji ${ }^{19}$. Ustawodawca ma przy tym możliwość wprowadzenia różnego rodzaju środków antyabuzywnych przeciwdziałających uzyskiwaniu nieuzasadnionych korzyści podatkowych z wykorzystaniem sztucznych struktur podatkowych ${ }^{20}$. Wówczas pomiędzy planowaniem podatkowym a unikaniem opodatkowania powstaje „szara strefa”21. Problem ten dotyczy przypadków, gdy dana struktura podatkowa nie spełnia definicji „sztuczności” przewidzianej w przepisach antyabuzywnych i wynika bezpośrednio z literalnego brzmienia przepisów podatkowych, a jednocześnie korzyści podatkowe z niej wynikające nie są akceptowane przez ustawodawcę $e^{22}$. Wówczas ustawodawca nie ma możliwości zanegowania korzyści podatkowych danej struktury podatkowej na podstawie przepisów antyabuzywnych, lecz musi dokonać nowelizacji przepisów ustaw podatkowych.

W polskim systemie podatkowym obowiązuje obecnie co najmniej kilka środków antyabuzywnych definiujących koncepcję sztucznej struktury podatkowej:

- klauzula ogólna obejścia prawa podatkowego (ang. general anti avoidance rules - GAAR) ${ }^{23}$ uznającą za sztuczne działania podatników,

${ }^{19}$ M. Kondej, Granice optymalizacji podatkowej w zakresie podatków dochodowych przed wejściem w życie klauzuli przeciwko unikaniu opodatkowania, Polskie Wydawnictwo Prawnicze IURIS, Poznań 2017, s. 76.

${ }^{20}$ Zobacz wyrok Trybunału Konstytucyjnego z dnia 11 maja 2004 r., sygn. K 4/03, https://ipo.trybunal.gov.pl/ipo/Szukaj?cid=1 (dostęp: 5.05.2018).

${ }^{21}$ Pojęciem szarej strefy posługuje się również M. Kalinowski w pracy Granice legalności unikania opodatkowania w polskim systemie podatkowym, Towarzystwo Naukowe Organizacji i Kierownictwa „Dom Organizatora”, Toruń 2001, s. 23, jednakże szara strefa według tej koncepcji to granica pomiędzy uchylaniem się od opodatkowania a planowaniem podatkowym.

${ }^{22}$ Dla przykładu należy wskazać struktury inwestycyjne, gdzie fundusz inwestycyjny zamknięty jest wspólnikiem w spółce osobowej transparentnej podatkowo (szerzej na ten temat zob. J. Jankowski, Optymalizacja podatkowa z wykorzystaniem funduszu inwestycyjnego zamkniętego, „Doradztwo Podatkowe - Biuletyn Instytutu Studiów Podatkowych” 2014, nr 5, s. 3-7). Niektórzy przedstawiciele doktryny klasyfikują te sytuacje jako tzw. zaawansowane planowanie podatkowe (tak J. Jankowski, Optymalizacja podatkowa w podatkach dochodowych - dopuszczalność i prawne granice, Wydawnictwo C.H. Beck, Warszawa 2019, s. 45).

${ }^{23}$ Istotą GAAR jest przyznanie organowi podatkowemu możliwości nieuznania na płaszczyźnie podatkowej skuteczności działań podejmowanych przez podatnika - legalnych, lecz zakwalifikowanych jako zmierzające do unikania opodatkowania 
które nie zostałyby zastosowane przez podmiot działający rozsądnie i kierujący się zgodnymi z prawem celami innymi niż osiągnięcie korzyści podatkowej sprzecznej z przedmiotem i celem przepisu ustawy podatkowej (art. 119c $\$ 1$ Ordynacji podatkowej ${ }^{24}$ ),

- klauzula szczególna dotycząca zagranicznych spółek kontrolowanych (ang. controlled foreign company - CFC) ${ }^{25}$ uznająca za „sztuczne struktury korporacyjne” zagraniczne spółki należące do polskich rezydentów, które nie prowadzą istotnej rzeczywistej działalności gospodarczej i są wykorzystywane do unikania opodatkowania dochodów krajowych i zagranicznych polskich rezydentów (art. 24a ustawy o podatku dochodowym od osób prawnych ${ }^{26}$ ).

Przepisy ustawy o podatku dochodowym od osób prawnych oraz Ordynacji podatkowej nie są jedynymi regulacjami, które przewidują wyjątki od ogólnych zasad opodatkowania w przypadku stwierdzenia, że działania podatnika są sztuczne, jednakże dla celów tworzenia mapy luki podatkowej dalsza analiza w tym zakresie nie jest zasadna. Analizując obecnie obowiązujące wewnątrzkrajowe i umowne środki antyabuzywne, można uznać, że sztuczne struktury podatkowe mogą mieć charakter krajowy bądź międzynarodowy. Międzynarodowe sztuczne struktury podatkowe mogą być wykorzystywane do unikania opodatkowania przez nierezydentów osiągających dochody na terytorium Polski oraz rezydentów polskich osiągających dochody krajowe i zagraniczne.

W przypadku zagranicznych wielooddziałowych koncernów (nierezydenci osiągający dochody na terytorium Polski) erozja podstawy opodatkowania może nie być rezultatem unikania opodatkowania sensu stricto, lecz rezultatem przerzucania dochodów pomiędzy jurysdykcjami podatkowymi wskutek stosowania nierynkowych rozliczeń pomiędzy podmiotami

(zob. A. Olesińska, Klauzula ogólna przeciwko unikaniu opodatkowania - moda czy konieczność, „Infos” nr 209 (5), 10.03.2016, s. 2.

${ }^{24}$ Ustawa z dnia 29 sierpnia 1997 r. Ordynacja podatkowa (tekst jedn. Dz.U. z 2017 r., poz. 201 ze zm.).

${ }^{25}$ Klauzula szczególna CFC przewiduje opodatkowanie udziałowca będącego krajowym rezydentem podatkowym z tytułu uzyskiwania dochodu przez kontrolowaną przez niego spółkę położoną za granicą, będącą rezydentem podatkowym innego państwa (zob. F. Majdowski, Stosowanie regulacji CFC w kontekście umów o unikaniu podwójnego opodatkowania - ocena stanowiska OECD (1), „Monitor Podatkowy” 2016, nr 9, s. 11).

${ }^{26}$ Ustawa z dnia 15 lutego 1992 r. o podatku dochodowym od osób prawnych (tekst jedn. Dz.U. z 2017 r., poz. 2343 ze zm.). 
powiązanymi w ramach grupy kapitałowej (ang. transfer pricing) ${ }^{27}$. Przerzucanie dochodów przez podmioty powiązane nie jest typowym unikaniem opodatkowania, ponieważ przepisy przeciwdziałające temu zjawisku mają odmienny charakter niż inne środki antyabuzywne ${ }^{28}$. Również statystyki dotyczące rezultatów prowadzonych kontroli podatkowych odróżniają ceny transferowe i unikanie opodatkowania ${ }^{29}$.

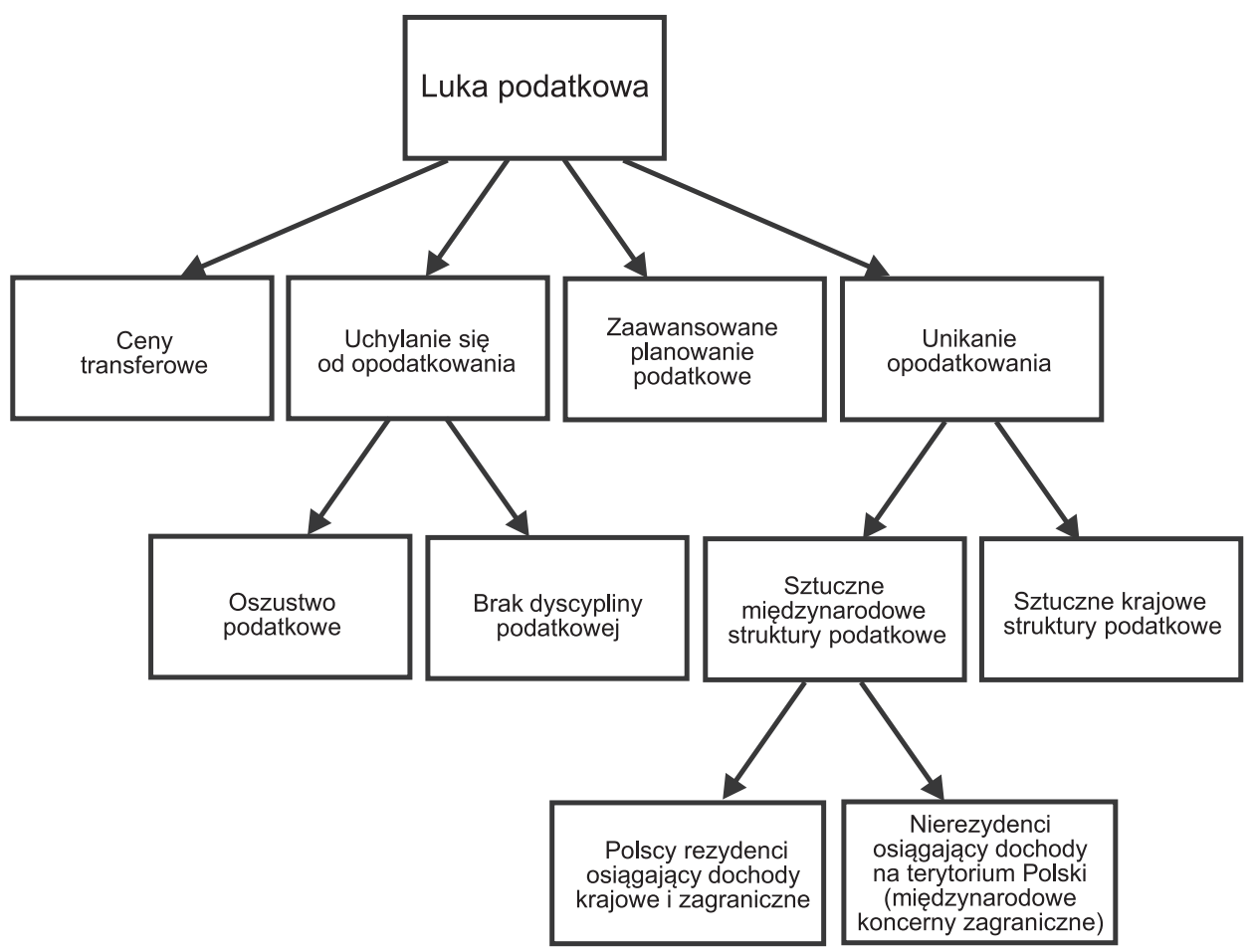

Rysunek. Struktura luki podatkowej w podatku dochodowym od osób prawnych Źródło: opracowanie własne.

${ }^{27}$ M. Jamroży, Ceny transferowe a reorganizacja działalności przedsiębiorstwa międzynarodowego, „Monitor Podatkowy” 2011, nr 4, s. 22.

${ }^{28} \mathrm{~W}$ przypadku środków antyabuzywnych skierowanych przeciwko sztucznym strukturom podatkowym przesłanki ich stosowania to kryteria kwalitatywne (chodzi o sposób działania), podczas gdy przesłanką zastosowania przepisów o cenach transferowych są kryteria kwantytatywne (stosowanie nierynkowych warunków transakcji) (por. P. Karwat, Klauzula ogólna a przepisy szczególne przeciwdziałajace unikaniu opodatkowania, „Przegląd Podatkowy” 2016, nr 12, s. 18).

${ }^{29}$ Prezentacja „Krajowa Administracja Skarbowa - Podsumowanie pierwszego roku funkcjonowania”, Warszawa, 8 marca 2018, https://www.mf.gov.pl/c/document_library/get_ file?uuid=4f94ee86-7240-4bf3-a7ed-17fd066963da\&groupId=764034 (dostęp: 5.05.2018). 
4. DotychCZASOWE SZACUNKI DLA POSZCZEGÓLNYCH OBSZARÓW LUKI PODATKOWEJ W PODATKU DOCHODOWYM OD OSÓB PRAWNYCH

\subsection{Uchylanie się od opodatkowania}

Problem luki podatkowej w podatku dochodowym od osób prawnych w odniesieniu do uchylania się od opodatkowania był dotychczas marginalizowany na rzecz innych obszarów luki podatkowej, w szczególności unikania opodatkowania. W statystykach publikowanych przez Ministerstwo Finansów trudno odnaleźć informację na temat wyników kontroli podatkowych w przedmiocie nielegalnego ukrywania dochodu czy błędnej kwalifikacji podatkowej stanów faktycznych lub prawnych ${ }^{30}$. Wydaje się, że przyczyną takiego stanu rzeczy jest przekonanie administracji skarbowej, iż problem uchylania się od opodatkowania nie ma większego znaczenia na gruncie podatku dochodowego od osób prawnych. Zjawisko to jest bowiem często utożsamiane wyłącznie z firmami z sektora MŚP prowadzącymi działalność w szarej strefie, mowa tu np. o niewystawianiu faktur przez spółkę kapitałową prowadzącą skład budowlany w mieście powiatowym średniej wielkości. Tymczasem problem uchylania się od opodatkowania na gruncie podatku dochodowego od osób prawnych nie powinien być bagatelizowany, zwłaszcza w aspekcie międzynarodowym. Międzynarodowe uchylanie się od opodatkowania może polegać w szczególności na:

- uniknięciu podatku u źródła w Polsce poprzez zadeklarowanie spółki pośredniczącej z państwa o łagodnym systemie podatkowym jako rzeczywistego właściciela odsetek i należności licencyjnych;

- niezgłoszeniu do opodatkowania w Polsce dochodu ze sprzedaży udziałów w spółce, której majątek stanowią nieruchomości położone w Polsce;

- przepływach pieniężnych pomiędzy podmiotami powiązanymi niezwiązanych z żadnymi dobrami lub usługami;

- ukrywaniu przez nierezydentów faktu powstania na terytorium Polski zagranicznego zakładu, którego zyski powinny być opodatkowane w Polsce ${ }^{31}$.

${ }^{30}$ M. Chądzyński, G. Osiecki, B. Godusławski, Morawiecki na tropie cen transferowych. Fiskus wychwyci podejrzane transakcje firm, „Dziennik Gazeta Prawna” 12.10.2017.

${ }^{31}$ D. Koreń, Kształtowanie obciążeń podatkowych $w$ stosunkach międzynarodowych, „Monitor Podatkowy” 2014, nr 8, s. 12. 
W przypadku uchylania się od opodatkowania ze względu na jego charakter jedynym wiarygodnym miernikiem poziomu luki podatkowej pozostają badania oparte na losowych kontrolach na reprezentatywnej próbie podatników ${ }^{32}$. Badania ankietowe lub oparte na danych pozyskiwanych przy okazji amnestii podatkowych nie pozwoliłyby na uzyskanie wiarygodnych wyników. W przypadku transgranicznych przepływów pieniężnych mających charakter nielegalnego transferu kapitału możliwe byłoby teoretycznie zastosowanie metody błędnego fakturowania (porównanie wielkości importu danego kraju z zagranicy z eksportem reszty świata do danego kraju) ${ }^{33}$.

\subsection{Zaawansowane planowanie podatkowe}

W przypadku zaawansowanego planowania podatkowego nie jest możliwe zastosowanie badania opartego na losowych kontrolach na reprezentatywnej próbie podatników, ponieważ funkcjonujące struktury podatkowe są rezultatem literalnego brzmienia przepisów oraz nie można w stosunku do nich postawić zarzutu sztuczności. Ustawodawca nie może wówczas zastosować środków antyabuzywnych, lecz musi dokonać nowelizacji przepisów ustaw podatkowych. W uzasadnieniu do projektu nowelizacji jest zazwyczaj zamieszczana ocena wpływu projektowanych zmian na budżet państwa. W latach 2014-2017 co najmniej dwie nowelizacje ustaw o podatkach dochodowych dotyczyły struktur podatkowych funkcjonujących w ramach zaawansowanego planowania podatkowego:

- odroczenie momentu opodatkowania dochodu z wykorzystaniem konstrukcji akcjonariusza spółki komandytowo-akcyjnej ${ }^{34}$;

- możliwość nieopodatkowanego transferu zysków do ostatecznego odbiorcy (zagranicznego rezydenta podatkowego) dzięki strukturze fundusz inwestycyjny zamknięty i spółka osobowa transparentna podatkowo ${ }^{35}$.

${ }^{32}$ A. Adamczyk, Zjawisko luki podatkowej w kształtowaniu warunków funkcjonowania przedsiębiorstw, „Zeszyty Naukowe Uniwersytetu Szczecińskiego. Ekonomiczne Problemy Usług" 2015, nr 116 (848), s. 606.

${ }^{33}$ K. Dąbrowska, M. Gruszczyński, Wycena transferowa, przenoszenie dochodów oraz inne aspekty umiędzynarodowienia przedsiębiorstw, „Ekonomia” 2004, nr 5, s. 125.

${ }^{34}$ Ustawa z dnia 8 listopada 2013 r. o zmianie ustawy o podatku dochodowym od osób prawnych, ustawy o podatku dochodowym od osób fizycznych oraz ustawy o podatku tonażowym (Dz.U. z 2013 r., poz. 1387).

${ }^{35}$ Ustawa z dnia 29 listopada 2016 r. o zmianie ustawy o podatku dochodowym od osób fizycznych, ustawy o podatku dochodowym od osób prawnych oraz ustawy o zmianie ustawy - Ordynacja podatkowa oraz niektórych innych ustaw (Dz.U. z 2016 r., poz. 1926). 
Wartość dodatkowych wpływów podatkowych z tytułu objęcia spółek komandytowo-akcyjnych podatkiem dochodowym od osób prawnych została oszacowana na kwotę ok. $294 \mathrm{mln} \mathrm{zt}^{36}$. W celu oszacowania kwoty wpływów przemnożono przeciętny dochód podatników podatku dochodowego od osób prawnych za rok 2011 w kwocie 0,8 mln zł (bez uwzględnienia banków i pozostałych instytucji finansowych) przez liczbę spółek komandytowo-akcyjnych z ostatniego okresu sprawozdawczego. Powyższa kwota została skorygowana na podstawie następujących czynników:

- możliwości dokonywania przez komplementariuszy będących zarówno osobami prawnymi, jak i osobami fizycznymi potrącenia od podatku z tytułu udziału w zysku w spółce komandytowo-akcyjnej,

- uwzględniono, że w przypadku akcjonariuszy będących osobami prawnymi zastosowanie znajdzie zwolnienie z dyrektywy unijnej.

W odniesieniu do struktury FIZ - spółka osobowa transparentna podatkowo kwota dodatkowych wpływów została oszacowana na poziomie 2-2,5 mld zł3 . Z danych publikowanych przez Komisję Nadzoru Finansowego wynika, że w roku 2015 fundusze inwestycyjne zamknięte osiągnęły pozytywny wynik z operacji na kwotę $12 \mathrm{mld}$ zł. Przy założeniu, że wynik finansowy funduszy byłby zbliżony do podstawy opodatkowania podatku dochodowego od osób prawnych, opodatkowanie tej kwoty powinno dawać wpływy właśnie w przedziale 2-2,5 mld zł.

\subsection{Unikanie opodatkowania}

W przypadku unikania opodatkowania dotychczasowe szacunkowe wyliczenia odnoszą się w zasadzie wyłącznie do międzynarodowych sztucznych struktur podatkowych, brak jest natomiast reprezentatywnych badań dla krajowych sztucznych struktur podatkowych. Statystyki dla międzynarodowych sztucznych struktur podatkowych często uwzględniają również ceny transferowe. Górna granica luki podatkowej z tego tytułu jest

${ }^{36}$ Uzasadnienie do rządowego projektu ustawy o zmianie ustawy o podatku dochodowym od osób prawnych, ustawy o podatku dochodowym od osób fizycznych oraz ustawy o podatku tonażowym, druk sejmowy nr 1725/VII kadencja, http://www.sejm.gov.pl/ sejm7.nsf/PrzebiegProc.xsp?nr=1725 (dostęp: 5.05.2018).

${ }^{37}$ Uzasadnienie do poselskiego projektu ustawy o zmianie ustawy o podatku dochodowym od osób fizycznych oraz ustawy o podatku dochodowym od osób prawnych, druk sejmowy nr 969/VII kadencja, http://www.sejm.gov.pl/Sejm8.nsf/druk.xsp?nr=969 (dostęp: 5.05.2018). 
szacowana na poziomie w przedziale 40-45 mld zł, jednakże zazwyczaj nie jest ona poparta żadnymi konkretnymi wyliczeniami. Przykładowo, Najwyższa Izba Kontroli oszacowała straty budżetu państwa z tytułu „międzynarodowego szkodliwego unikania opodatkowania" na poziomie nie mniejszym niż 8,5 mld zł, powołując się na szacunki czeskiej administracji skarbowej z 2011 r. ${ }^{38}$ Autorzy raportu 600 mld euro i... rośnie: Dlaczego wysoko opodatkowane kraje pozwalaja rozkwitać rajom podatkowym ${ }^{39}$ ocenili straty polskiego budżetu $\mathrm{z}$ tytułu międzynarodowego unikania opodatkowania na prawie 20\% CIT zebranego w $2015 \mathrm{r}^{40}$ Według szacunków OECD poziom utraty wpływów podatkowych z tytułu BEPS waha się w przedziale od $4 \%$ do $10 \%$ globalnej kwoty wpływów podatkowych z podatku dochodowego od osób prawnych ${ }^{41}$. Analitycy SGH, powołując się na dane administracji skarbowej Stanów Zjednoczonych, określili wysokość luki z tego

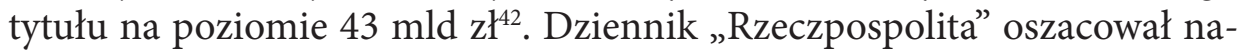
tomiast straty budżetu państwa $\mathrm{z}$ tytułu międzynarodowych sztucznych struktur podatkowych stosowanych przez polskich rezydentów na kwotę 3,3 mld $\mathrm{z}^{43}$. Ministerstwo Finansów w roku 2014 oficjalnie potwierdziło, że nie jest w stanie określić szacunkowej kwoty ubytków wpływów podatkowych $\mathrm{z}$ tego tytułu ${ }^{44}$. Przepisy CFC w pierwszym roku obowiązywania przyniosły budżetowi państwa jedynie $11 \mathrm{mln} \mathrm{z}^{45}$. Wiele firm przebudowało albo zlikwidowało swoje zagraniczne struktury ${ }^{46}$. Jednocześnie, jak

${ }^{38}$ Raport NIK „Nadzór organów podatkowych i organów kontroli skarbowej nad prawidłowością rozliczeń $\mathrm{z}$ budżetem państwa podmiotów $\mathrm{z}$ udziałem kapitału zagranicznego" z dnia 17 kwietnia 2015 r., nr 27/2015/p/14/013/kbF, https:/www.nik.gov.pl/plik/ id,8681,vp,10800.pdf (dostęp: 21.04.2018).

${ }^{39}$ Raport NBP „Polskie inwestycje bezpośrednie za granicą w 2016 roku”, http:// www.nbp.pl/publikacje/pib/pib_2016_n.pdf (dostęp: 13.05.2018).

${ }^{40}$ M. Szulc, Jak nasze pieniądze uciekały do rajów podatkowych, „Dziennik Gazeta Prawna" 27.11.2017.

${ }^{41}$ OECD „Measuring and Monitoring BEPS, Action 11 - 2015 Final Report”, s. 79.

${ }^{42}$ A. Cieślak-Wróblewska, Ponad 40 mld zł luki w podatku CIT, „Rzeczpospolita” 16.03.2017.

${ }^{43} \mathrm{P}$. Rochowicz, Miliardy strat $w$ budzecie przez zwłokę $w$ ogłoszeniu ustawy o zagranicznej spótce kontrolowanej, „Rzeczpospolita” 3.10.2014.

${ }^{44}$ MF: nie możemy oszacować skali transferów do rajów podatkowych, „Dziennik Gazeta Prawna" 8.12.2014.

${ }^{45}$ M. Szulc, Opodatkowanie CFC nie przyniosło kokosów, „Dziennik Gazeta Prawna” 3.01.2017.

${ }^{46} \mathrm{P}$. Rochowicz, Korzyści z ustawy o rajach podatkowych będą znane za rok, „Rzeczpospolita" 2.10.2015. 
wynika z danych NBP dotyczących polskich inwestycji zagranicznych, polscy rezydenci nadal posiadali znaczące aktywa ulokowane na Cyprze czy w Luksemburgu ${ }^{47}$. Statystyki te potwierdzają dużą rolę tych jurysdykcji podatkowych w unikaniu opodatkowania dochodów (krajowych i zagranicznych) polskich rezydentów podatkowych ${ }^{48}$.

Do oszacowania wysokości luki podatkowej na skutek unikania opodatkowania przez krajowe przedsiębiorstwa osiągające dochody krajowe i zagraniczne możliwe jest wykorzystanie efektywnej stopy opodatkowania tychże podatników w poszczególnych jurysdykcjach podatkowych, w których prowadzili działalność. Badana jest wówczas zależność pomiędzy tymi stopami a udziałem takich zmiennych, jak: sprzedaż, wartość dodana, wartość aktywów, liczba pracowników, wysokość wynagrodzeń i wysokość dochodu przed opodatkowaniem dla spółek zlokalizowanych w tych jurysdykcjach ${ }^{49}$.

\subsection{Ceny transferowe}

Centrum Analiz Klubu Jagiellońskiego w raporcie Znikające miliardy. Jak transfer dochodów za granice drenuje polski budżet oszacowało kwotę

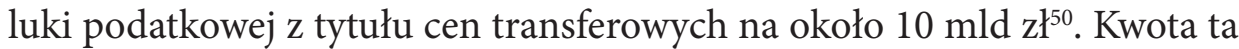
została oszacowana przez analityków na podstawie następujących statystyk podatku dochodowego od osób prawnych z poszczególnych lat:

- liczby podatników podatku dochodowego od osób prawnych,

- kwoty zagregowanych dochodów i przychodów,

- udziału wpływów z podatku dochodowego od osób prawnych w PKB.

Parametry te rzeczywiście mogą zostać wykorzystane do szacowania luki podatkowej w podatku dochodowym od osób prawnych, jednakże trudno na tej podstawie wywnioskować, jaka część tej kwoty dotyczy cen transferowych. Podobnie jak w przypadku międzynarodowego unikania

${ }^{47}$ T. Torslov, L. Wier, G. Zucman, E 600 Billion and Counting: Why High-Tax Countries Let Tax Havens Flourish, 2017, https://gabriel-zucman.eu/files/TWZ2017.pdf (dostęp: 12.05.2018).

${ }^{48} \mathrm{~J}$. Jankowski, Symptomy istnienia luki podatkowej w podatku dochodowym od osób prawnych, „Monitor Podatkowy” 2019, nr 2, s. 25-26.

${ }^{49}$ M.M. Hybka, Możliwości zapobiegania agresywnemu planowaniu finansowemu, „Kwartalnik Kolegium Ekonomiczno-Społecznego Studia i Prace” 2015, nr 3, s. 118.

${ }^{50}$ R. Piekarz, A. Miarkowski, Znikające miliardy. Jak transfer dochodów za granice drenuje polski budżet, http://cakj.pl/wp-content/uploads/2015/09/Znikaj\%C4\%85cemiliardy.pdf (dostęp: 13.05.2018). 
opodatkowania, Ministerstwo Finansów oficjalnie nie posiada szacunków dla obszaru cen transferowych ${ }^{51}$.

Skalę zjawiska przerzucania dochodów można oszacować poprzez analizę wskaźników finansowych danej branży gospodarki i odniesienie ich do współczynników rozliczeń podatkowych konkretnych podmiotów zagranicznych. W pierwszej fazie, posługując się różnymi miernikami, bada się ogólny związek pomiędzy dochodowością a zobowiązaniami podatkowymi i uwzględnia zarówno podmioty krajowe, jak i zagraniczne z danej branży (wyniki ogólnobranżowe) ${ }^{52}$. Następnie ustala się, czy wyniki wyłącznie podmiotów zagranicznych wykazują znaczące odchylenie od wyników ogólnobranżowych (czy zależność pomiędzy dochodami i podatkami może być negatywna) ${ }^{53}$. Finalnie dokonuje się analizy wyników konkretnego podmiotu zagranicznego i „podobnych” do niego spółek krajowych (np. struktura aktywów), które nie są firmami globalnymi i nie uczestniczą w transferze dochodów.

\section{Podsumowanie}

Na mapę luki podatkowej w podatku dochodowym od osób prawnych składają się: uchylanie się od opodatkowania, zaawansowane planowanie podatkowe, unikanie opodatkowania oraz ceny transferowe. Powyższy podział, choć nie oddaje w pełni wszelkich możliwych form oporu podatkowego, to jednak pozwala na stworzenie mapy luki podatkowej umożliwiającej bieżące monitorowanie skali zjawiska erozji podstawy opodatkowania i transferu dochodów w Polsce. Wyłącznie w sytuacji dysponowania „pełnym obrazem" luki podatkowej podatku dochodowego od osób prawnych ustawodawca będzie mógł stworzyć kompleksowy program efektywnie ograniczający rozmiary tego zjawiska. Problem ten nie powinien być bagatelizowany, ponieważ najnowsze badania wskazują na istotność problemu

${ }^{51}$ Jak czytamy w odpowiedzi podsekretarza stanu w Ministerstwie Finansów Leszka Skiby z dnia 3 czerwca 2016 r. (nr PM2.054.2.2016) na interpelację poselską posła Józefa Brynkusa nr 2940 z dnia 17 maja 2016 r., „Niektóre podmioty powiązane mogą korzystać z instrumentów służących do przerzucania dochodów pomiędzy poszczególnymi jurysdykcjami podatkowymi, takich jak ceny transferowe. MF nie posiada jednak szczegółowych szacunków skali tego zjawiska”.

${ }^{52}$ A. Jurkowska, Czy banki zagraniczne transferuja zyski, „Zeszyty Naukowe Uniwersytetu Ekonomicznego w Krakowie” 2008, nr 778, s. 89.

${ }^{53}$ Ibidem. 
luki podatkowej w podatku dochodowym od osób prawnych ${ }^{54}$. Z opracowań tych wynika, że wysokość luki podatkowej w latach 2016-2017 mieściła się w przedziale 15-20 mld zł.

\section{BibliografiA}

Adamczyk A., Czynniki kształtujące dochody z tytułu podatku dochodowego od osób prawnych $w$ Polsce na tle państw Unii Europejskiej, cz. 1, „Finanse, Rynki Finansowe, Ubezpieczenia" 2016, nr 5 (83).

Adamczyk A., Zjawisko luki podatkowej w kształtowaniu warunków funkcjonowania przedsiębiorstw, „Zeszyty Naukowe Uniwersytetu Szczecińskiego. Ekonomiczne Problemy Usług" 2015, nr 116 (848).

Biernacki K., Brodzka A., Chodorek M., Efektywne stawki podatku dochodowego w Polsce - na przykładzie spółek indeksu WIG 20, „Nauki o Finansach” 2016, nr 1 (26).

Chądzyński M., Godusławski B., Uszczelnianie CIT bardziej skomplikowane niż VAT. W resorcie finansów sypia się głowy za opóźnienia, „Dziennik Gazeta Prawna” 5.04.2018.

Chądzyński M., Osiecki G., Godusławski B., Morawiecki na tropie cen transferowych. Fiskus wychwyci podejrzane transakcje firm, „Dziennik Gazeta Prawna” 12.10.2017.

Cieślak-Wróblewska A., Ponad 40 mld zł luki w podatku CIT, „Rzeczpospolita” 16.03.2017.

Dąbrowska K., Gruszczyński M., Wycena transferowa, przenoszenie dochodów oraz inne aspekty umiędzynarodowienia przedsiębiorstw, „Ekonomia” 2004, nr 5.

Grycuk A., Podatek CIT jako narzędzie polityki gospodarczej, „Infos” nr 4 (74), 18.02.2010.

Hybka M.M., Możliwości zapobiegania agresywnemu planowaniu finansowemu, „Kwartalnik Kolegium Ekonomiczno-Społecznego Studia i Prace" 2015, nr 3.

Hybka M.M., Struktura, metody szacowania oraz instrumenty ograniczania luki podatkowej $w$ Wielkiej Brytanii i Stanach Zjednoczonych Ameryki, cz. 2, „Finanse, Rynki Finansowe, Ubezpieczenia" 2016, nr 5 (83).

Jamroży M., Ceny transferowe a reorganizacja działalności przedsiębiorstwa międzynarodowego, „Monitor Podatkowy” 2011, nr 4.

Jankowski J., Kwantyfikacja poziomu efektywności fiskalnej podatku dochodowego od osób prawnych w Polsce, „Monitor Podatkowy” 2019, nr 5.

Jankowski J., Optymalizacja podatkowa w podatkach dochodowych - dopuszczalność i prawne granice, Wydawnictwo C.H. Beck, Warszawa 2019.

Jankowski J., Optymalizacja podatkowa $z$ wykorzystaniem funduszu inwestycyjnego zamkniętego, „Doradztwo Podatkowe - Biuletyn Instytutu Studiów Podatkowych” 2014, nr 5.

Jankowski J., Symptomy istnienia luki podatkowej w podatku dochodowym od osób prawnych, „Monitor Podatkowy” 2019, nr 2.

${ }^{54}$ Zobacz J. Jankowski, Kwantyfikacja poziomu efektywności fiskalnej podatku dochodowego od osób prawnych w Polsce, „Monitor Podatkowy” 2019, nr 5, s. 33, oraz raport Horyzont optymalizacji - geneza, skala $i$ struktura luki w podatku CIT zaprezentowany przez Polski Instytut Ekonomiczny w dniu 24 kwietnia 2019 r., http://pie.net.pl/wp-content/ uploads/2019/04/PIE-Raport_CIT.pdf (dostęp: 1.05.2019). 
Jurkowska A., Czy banki zagraniczne transferuja zyski, „Zeszyty Naukowe Uniwersytetu Ekonomicznego w Krakowie" 2008, nr 778.

Kalinowski M., Granice legalności unikania opodatkowania w polskim systemie podatkowym, Towarzystwo Naukowe Organizacji i Kierownictwa „Dom Organizatora”, Torun 2001.

Karwat P., Klauzula ogólna a przepisy szczególne przeciwdziałające unikaniu opodatkowania, „Przegląd Podatkowy” 2016, nr 12.

Klonowska A., Rozpoznanie obszarów ryzyka podatkowego jako metoda zwiększania wpływów podatkowych, Uniwersytet Ekonomiczny w Krakowie, Kraków 2016.

Kondej M., Granice optymalizacji podatkowej w zakresie podatków dochodowych przed wejściem w życie klauzuli przeciwko unikaniu opodatkowania, Polskie Wydawnictwo Prawnicze IURIS, Poznań 2017.

Koreń D., Kształtowanie obciążeń podatkowych $w$ stosunkach międzynarodowych, „Monitor Podatkowy" 2014, nr 8.

Kurzac M., Uchylanie się od opodatkowania i oszustwo podatkowe w rozumieniu art. 54 i 56 Kodeksu karnego skarbowego w świetle odesłań do systemu prawa podatkowego, „Studia Prawno-Ekonomiczne” 2017, t. 102.

Kurzac M., Unikanie opodatkowania a uchylanie się od opodatkowania - o kryteriach rozróżniających, „Studia Prawno-Ekonomiczne” 2017, t. 105.

Kuźniacki B., Skuteczność polskich ogólnych norm prawnopodatkowych jako narzędzi potencjalnie stużacych zwalczaniu unikania opodatkowania przez wykorzystanie kontrolowanych zagranicznych spółek, „Toruński Rocznik Podatkowy” 2012.

Majdowski F., Stosowanie regulacji CFC w kontekście umów o unikaniu podwójnego opodatkowania - ocena stanowiska OECD (1), „Monitor Podatkowy” 2016, nr 9.

Małecka-Ziembińska E., Luka w podatku od towarów i usług i sposoby jej ograniczania, „Kwartalnik Kolegium Ekonomiczno-Społecznego Studia i Prace” 2017, nr 1.

MF: nie możemy oszacować skali transferów do rajów podatkowych, „Dziennik Gazeta Prawna" 8.12.2014.

OECD „Measuring and Monitoring BEPS, Action 11 - 2015 Final Report”.

Olesińska A., Klauzula ogólna przeciwko unikaniu opodatkowania - moda czy konieczność, „Infos” nr 209 (5), 10.03.2016.

Piekarz R., Miarkowski A., Znikające miliardy. Jak transfer dochodów za granice drenuje polski budżet, http://cakj.pl/wp-content/uploads/2015/09/Znikaj\%C4\%85ce-miliardy.pdf (dostęp: 13.05.2018).

Pietrasz P., Opodatkowanie dochodów nieujawnionych, Wolters Kluwer, Warszawa 2007.

Radzikowski K., Obejście prawa podatkowego w najnowszym orzecznictwie sądów administracyjnych, „Przegląd Podatkowy” 2010, nr 6.

Raport Horyzont optymalizacji - geneza, skala i struktura luki w podatku CIT zaprezentowany przez Polski Instytut Ekonomiczny w dniu 24 kwietnia 2019 r., http://pie.net. pl/wp-content/uploads/2019/04/PIE-Raport_CIT.pdf (dostęp: 1.05.2019).

Raport NBP „Polskie inwestycje bezpośrednie za granicą w 2016 roku”, http://www.nbp. pl/publikacje/pib/pib_2016_n.pdf (dostęp: 13.05.2018).

Raport NIK „Nadzór organów podatkowych i organów kontroli skarbowej nad prawidłowością rozliczeń $\mathrm{z}$ budżetem państwa podmiotów $\mathrm{z}$ udziałem kapitału zagranicznego" z dnia 17 kwietnia 2015 r., nr 27/2015/p/14/013/kbF, https://www.nik.gov.pl/ plik/id,8681,vp,10800.pdf (dostęp: 21.04.2018). 
Rochowicz P., Korzyści z ustawy o rajach podatkowych będa znane za rok, „Rzeczpospolita” 2.10.2015.

Rochowicz P., Miliardy strat $w$ budżecie przez zwłokę $w$ ogłoszeniu ustawy o zagranicznej spółce kontrolowanej, „Rzeczpospolita” 3.10.2014.

Sosnowski M., Sprawność fiskalna podatków dochodowych, cz. 1, „Finanse, Rynki Finansowe, Ubezpieczenia” 2016, nr 5 (83).

Sowiński R., Uchylanie się od opodatkowania, Wydawnictwo Naukowe UAM, Poznań 2009.

Szulc M., Jak nasze pieniądze uciekały do rajów podatkowych, „Dziennik Gazeta Prawna” 27.11.2017.

Szulc M., Opodatkowanie CFC nie przyniosło kokosów, „Dziennik Gazeta Prawna” 3.01.2017.

Torslov T., Wier L., Zucman G., E 600 Billion and Counting: Why High-Tax Countries Let Tax Havens Flourish, 2017, https://gabriel-zucman.eu/files/TWZ2017.pdf (dostęp: 12.05.2018).

\section{MAP OF THE TAX GAP IN CORPORATE INCOME TAX}

Summary. Map of the tax gap in corporate income tax In highly developed countries, the programs of measuring tax gap have been successfully implemented since the seventies of XX century. In the case of corporate income tax, estimation of the amount and determining the structure of the tax gap in CIT is much more complex matter than in the case of VAT. The Polish Ministry of Finance is claimed to have its own calculations in this respect, however they have not been published so far. Available foreign literature on estimating tax losses of the state budget due to the tax gap concerns only selected (specific) areas of the tax gap. In addition, the possibilities of its application in the specific conditions of the Polish tax system are limited. The publication attempts to create a map of the tax gap for CIT purposes.

Keywords: tax avoidance, profit shifting, tax gap, corporate income tax 